\title{
断層撮影法における二三の問題
}

\author{
茅室町立病院放射線科
}

富樫健

（論交受付 5 月26日）

\section{A FEW PROBLEMS ON LAMINOGRAPHY}

\section{By TAKESHI TOGASHI}

Department of Radiology

Kayamuro Municipal Hospital

(Article recieved : May 26, 1958)

\section{Summary}

With a certain kind of planagraph apparatus there in an inevitable prolongation of the time of projection with changes in the transversal angle.

The calculation has been difficult and has been apt to depend on experience and intuition. Therefore, the author with a stroboscope measured the time of projection and the exect incidence angle of each transversal angle and calculated energy of X-ray putting all the results together to make a simple and practical exposure chart for planagraphy.

\section{1.まえがき}

X線を人体に照射するに際し，当初に考えられること に, 電圧一電流一懪射時間の三要素に有ると思う.

現今における撮影術式に桷川氏・内田氏等に依る指数 函数的撮影法・電子的撮影法の所謂係数撮影法により, 科学的な解決, 処理でき得ることは既に衆知の通りであ る.

しかしながら，との基礎は電圧一電流一懪射時間の三 要素並びに諸の条件を適当な配分によって决定付けられ るちのであって，その内の何れかが不明であっては，こ の方程式の成立は困難をきたすことは敢て贅言を必要々 しない。

断層撮影䒾置における撮影にあたっての問題点に先ず 曝射時間の不明がある。

このことはあるいは一片の疑義をはさむ余地があるか も知れぬが，と謂うことは，装置製造メーカーによって 製作方法の差違があり。

a 断層角度の変化に関係なく曝射時間を任意に選定 でき得る。

ものと

b 断層角度の変化に関係なく管球移動速度を一定に 調節でき得る。

c 断層角度の変化に従ひ曝射時間も変更され得るも
の.

とに区分されるものと思うか， b c $の$ 場合の曝射時 間は不明である。

即ち, b c の場合の曝射時間は Photo. 1 及び Fig. 1 の如く，痛笨の如何によって变化する断圈角度によって 決定されるすのであり，各断層角度によってX線曝射時 間も異なることは図によっても明白である。

当科装置は $\mathrm{c}$ 亿当嵌り，従って管球移動速度は断層角 度の変化に非干涉であり一定であるならば，X線曝射時 間は断層角度決定摺動接点の軌道の長さ（角度板）に比

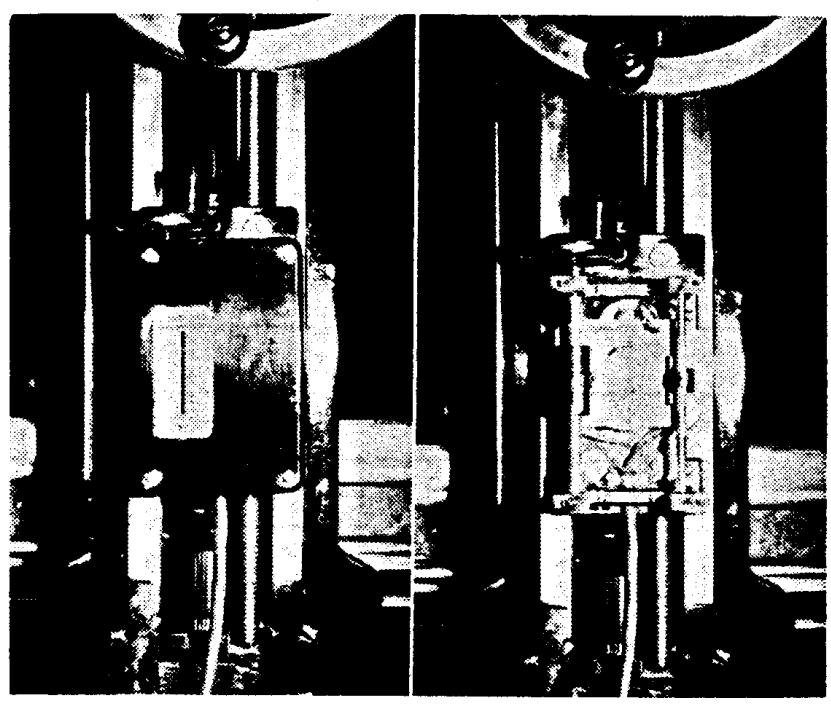

Photo. 1 
例するうのであり，角度の大いなるに従ってX線曝射時 間も長くなる。

故亿制御器の限時装置は公く関係なく, 曝射楾量は飽

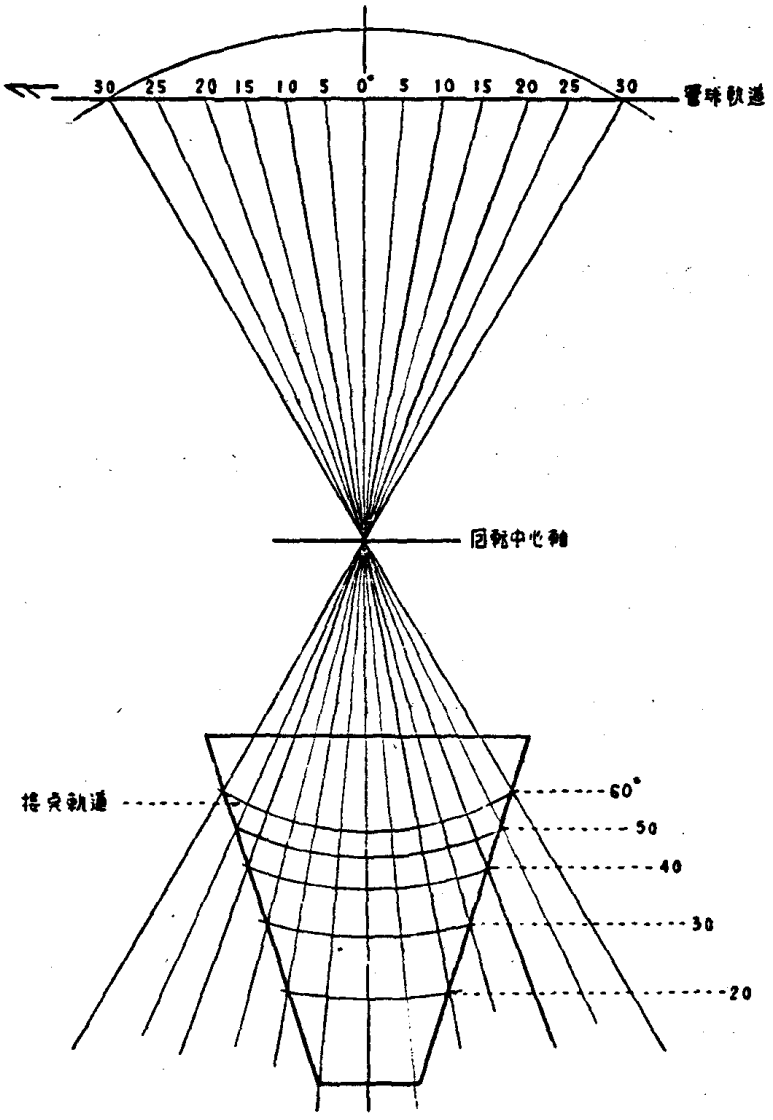

Fig. 1 断面角度決定（放射時間）用摺動接点模型图
迄推量に過ぎない。

早近な例として筆者自身，経臥と感頼って操作して よることは事実である。

ここで網川氏1゙よる簡易な stroboscopy によって実 験，測定を試み断風撮影に関する二，三の問題を解決せ

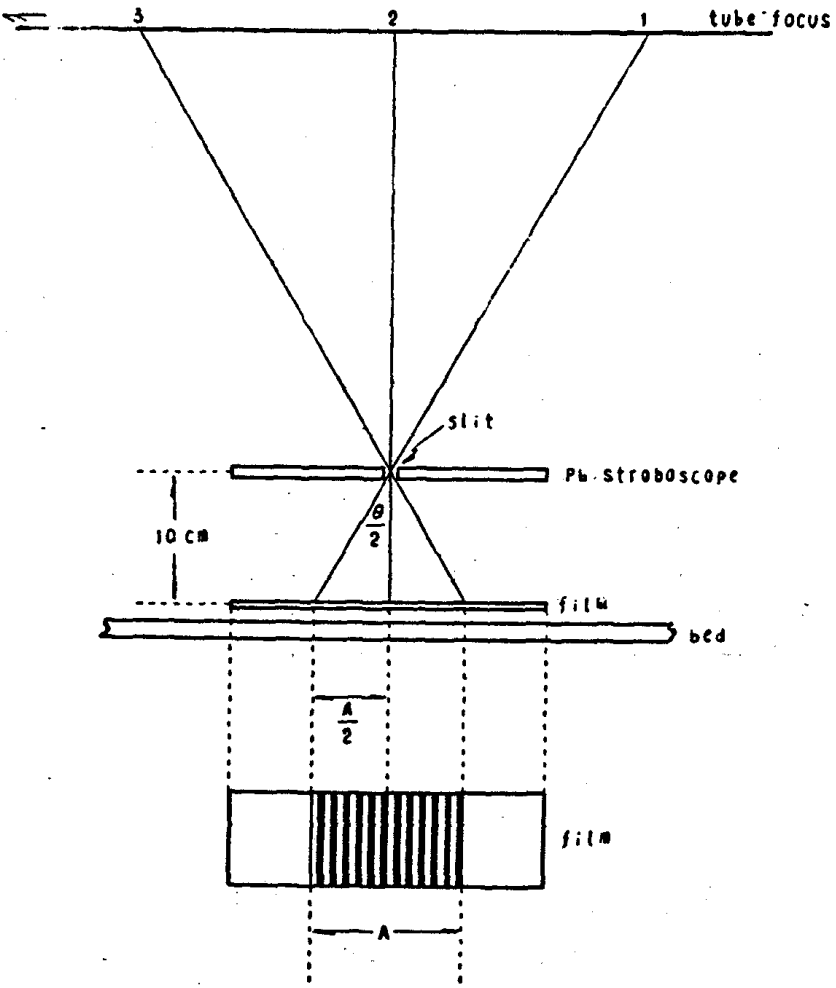

Fig. 2

Table. 1

\begin{tabular}{|c|c|c|c|c|c|c|c|c|c|c|c|}
\hline $\begin{array}{c}\theta \\
0 \\
0\end{array}$ & slit照目韵 & 91: & $\begin{array}{c}t \\
t=\frac{N}{2 t} \\
\text { s.e.c }\end{array}$ & $\begin{array}{c}\theta \\
\theta=2\left(\tan \frac{A}{20}\right) \\
\therefore\end{array}$ & $\begin{array}{c}\alpha \\
\alpha=x-\beta-0 \cdot \frac{1}{2} \\
.\end{array}$ & $\begin{array}{c}d=\tan \alpha \cdot b \\
m\end{array}$ & $\begin{array}{c}C \\
c=\sqrt{a^{2}+B} \\
m\end{array}$ & $\begin{array}{c}\mu \\
\mu=\frac{c}{b} \\
\%\end{array}$ & $D$ & $\begin{array}{c}E \\
E=\frac{\text { eAs. } \frac{k T p}{D}}{\text { energy }} \\
\end{array}$ & $\begin{array}{c}\text { tube } \\
\text { voltage } \\
\text { xrp }\end{array}$ \\
\hline 0 & & - & $\longrightarrow$ & 0.0 & 0.0 & $\longrightarrow$ & 1010.0 & 1 & 10010.0 & & - \\
\hline 20 & 27 & 31 & 0.27 & 17.36 & 8.18 & $156 . \overline{3}$ & 1022.1 & 0.9882 & 3054.2 & 0.380 & 12 \\
\hline 25 & 31 & 42 & 0.37 & 23.42 & 11.51 & 211.8 & 1032.0 & 0.9785 & & & \\
\hline 30 & 12 & 47.5 & 042 & 26.10 & 13.05 & 234.7 & 1036.9 & 0.9741 & 5128.0 & 0.333 & 68 \\
\hline 35 & 50 & 56.5 & 0.50 & 31.32 & 15.46 & 285.1 & 1049.5 & 0.9624 & & . & \\
\hline 40 & 61 & 67.5 & 0.61 & 37.16 & 18.38 & 340.4 & 1065.9 & 0.9476 & 7259.8 & 0.322 & 64 \\
\hline 45 & 15 & 82 & 0.75 & 41.34 & 22.11 & 413.7 & 1091.5 & 0.9253 & & & . \\
\hline 50 & 81 & 93.5 & 0.87 & 50.06 & 25.03 & 471.9 & 1114.9 & 0.9059 & 9489.6 & 0.330 & 60 \\
\hline 55 & 102 & 107.5 & 1.02 & 56.300 & 20.15 & 542.6 & 1146.6 & 0.8810 & & $\cdot$ & \\
\hline 60 & 124 & 126 & 1.24 & 64.21 & 32.12 & 635.9 & 1193.6 & 0.8462 & 11876.8 & 0.350 & 56 \\
\hline
\end{tabular}


んとした。

\section{2. 使用せる装置}

島津製 300mA 型単相全波整流装置切替併用方式 " 横型断面撮影装置 (planigraph 式) 名完角度調節範囲 $20^{\circ} \sim 60^{\circ} 5^{\circ}$ 間隔 管球 SDR-10S 実効焦点 $3.5 \times 3.5 \mathrm{~mm}$ 自製 stroboscope slit $\sim 1 \mathrm{~mm}$

\section{3. 実験方法及び実験結果}

stroboscope は Fig. 2 の如人至極簡単なものである. 元来ての応用の診断用装置における限時装置の精密度試 験代用いられておるちのであり，電磁oscillograph 及び cycle counter の測定器具等よりなお一層の簡潔さが賞 用されており，我々技術者であるなら一度は経験した筈
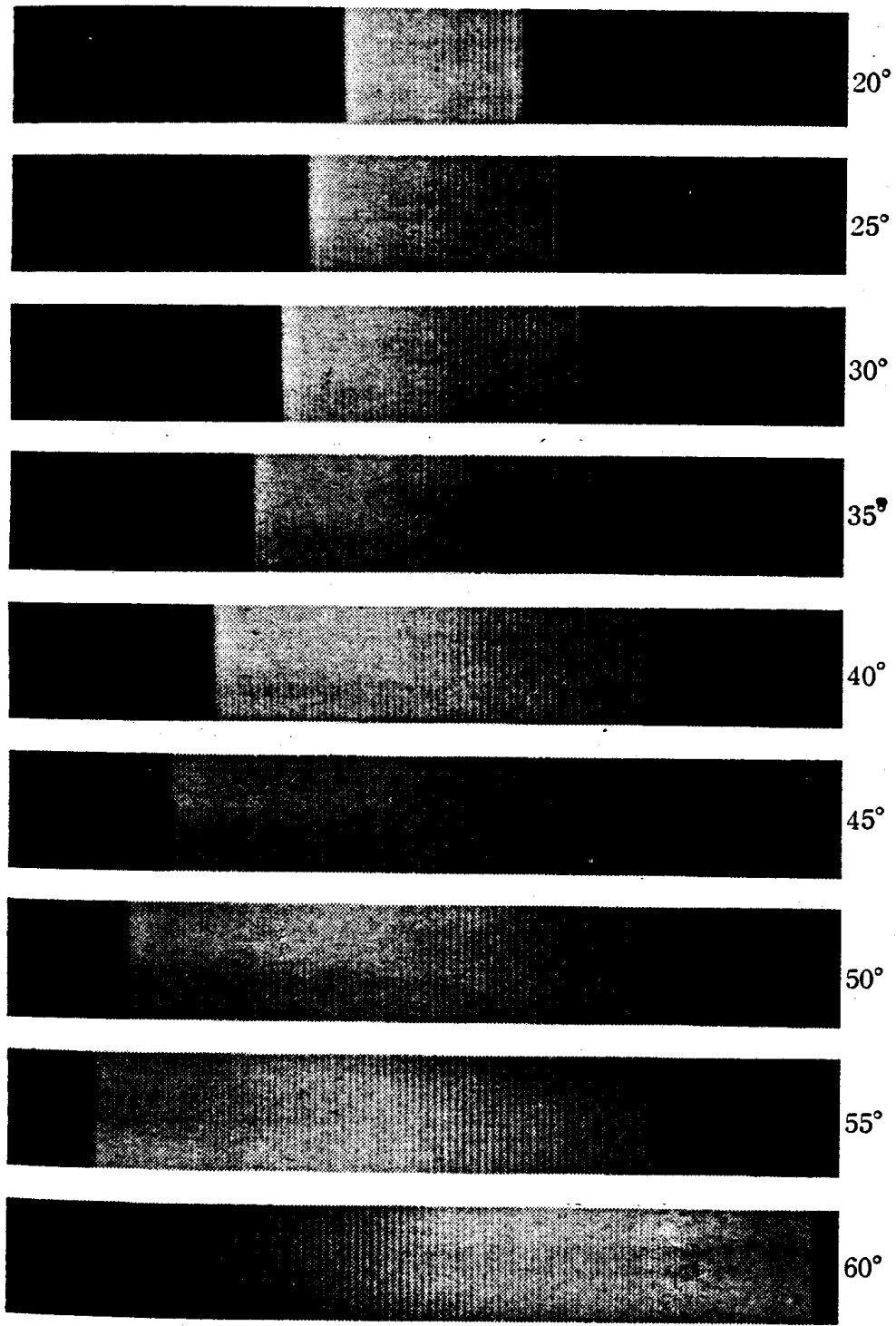

Photo 2
のものであって格別珍らしいちのでないが，本来ならば stroboscope 自体を迴転あるいは移動させてX線を放射 させるのであるが，断增の場合には管球が移動するので， stroboscope は固定できうる便がある，従ってての方法 を用いて各断層角度別一 $20^{\circ} \sim 60^{\circ} \cdot 5^{\circ}$ 間隔一亿管球を振 らせてX線曝射を試みるならば Photo. 2 の如く白い

（filmには黒く）縞目となって表われる.

この繑目はX線管の陽函に正電荷かかかかった時にX線 が放射されるから film 上には周波数に応じた縞目があ ることになる。

大体, 静岡県富士川以東では 50 cycle (の)である. 全波整流装置では

$$
\begin{aligned}
& 0.1 \mathrm{sec} \sim 10 \\
& 1.0 \mathrm{sec} \sim 100
\end{aligned}
$$

のX線が陽極より故出されておる訳である。

ての現出された縞目より

\section{a 各断啳角度における X線㬐射時間 \\ e 実際の断屏角度 \\ c 䜳流管機能の良否3)}

などが判然とする。

以下若干の詳述を加える。

\section{A 各断屈角度におけるX線喂射時間}

strobogram に表われた縞目の数 $N$ （放射回 数) そよって

$$
\begin{gathered}
\frac{N}{2 f}=t \\
f=\text { frequency } \\
t=\text { exposure time (sec) }
\end{gathered}
$$

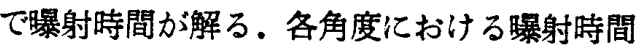
は Table. 1 の如くである.

\section{B 実際の断属角度}

現出された縞目の幅 A 一即ち Fig. 2 の如き Aなる幅計測し（計測結果 Tobe. 1)

$$
\begin{aligned}
\tan \frac{\theta}{2} & =\frac{\frac{A}{2}}{10}=\frac{A}{20} \\
\frac{\theta}{2} & =\tan \frac{A}{20} \\
\theta & =2\left(\tan \frac{A}{20}\right)
\end{aligned}
$$

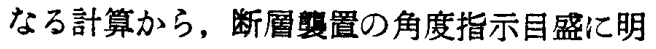
示されておるものより,なお精確な角度（実放 射角度) が算出され得るものである. Table. 1

この縞目数及ご $A$ 幅は各角度とも 3 回宛撮影 及び計測を行い，それを平均したものの数值で 
あろ.

結果として余り大きな誤差はなかった，0.01〜0.05 程 度の違いは中にはあったが略一致した値が得られた。

この差違の原因は，Photo. 1のような角度指示目盛 に指針を合致するに際しての目測の伍い，あるいはX線 電磁䦎閉器の開閉動作の早遅及び cycle 数変化等の自然 的な問題も誤差の原因に含まれても差支えないものと考 えられるが，何れにしろこの程度の差は何等影響はない と思う。またとれによって管球移動速度の安定性がみら れたことは有力な副産物であったといえよう。

\section{C 流管機能の良否}

正常の連続したるの, 縞目の中で整流管機能の不良の ちのがあれば一定の黒化した縞目の中から直識別し得 ろ.

即ち, 整流管に電流が通じてX線管を通りX線を放出 するべきところを電流が流れないから（織条断線）ある 一定の縞目だけが現出されない．また織条電流不足等の 場合にはその個処の黒化不足となっている．との場合整 流管を1本ずつ引抜いて検討する必要がある。

てれらの問題は㞗々遭用しておることなので殊更の実 耠は省略する。

\section{D 撮影条件の検討}

以上の測定結果より曝射時間が判明せられたので撮影 条件を検討してみた。

元来, X線撮影条件の基整として film 亿一定の濃度 を生ずるに要するX線エネルギー $(E)$ は

$$
E=K \cdot \frac{T \cdot \mathrm{mA} \cdot \mathrm{kVp}^{\prime 2}}{d^{2}},
$$

$T=$ exposure time $(\mathrm{sec})$

$\mathrm{mA}=$ plate current $\sim$ mean value

$\mathrm{kVp}=$ plate voltage $(n=3 \sim 5) \sim$ peak value

$d^{2}=$ focus $\sim$ film distance $(\mathrm{mm})$

$K=$ const

なる基本式がある。

こてで仮に $K=n=$ const とするなら式を簡略にして

$$
\begin{aligned}
& E=\frac{(T \cdot \mathrm{mA}) \mathrm{kVp}}{d^{2}} \\
& E=\frac{\mathrm{mAs} \cdot \mathrm{kVp}}{d^{2}}
\end{aligned}
$$

で概略算出し得るすのである．がここで問題となるの はd (focus〜film distance) の值であって, 断读撮影に 際しては管球の移動に伴って $\mathrm{d}$ の距離 る逐一変動々一定 でなくまたてのためにX線入射角の変化に追従する被 写物体の厚みが吸収に依る減弱保数も異なり, inten-

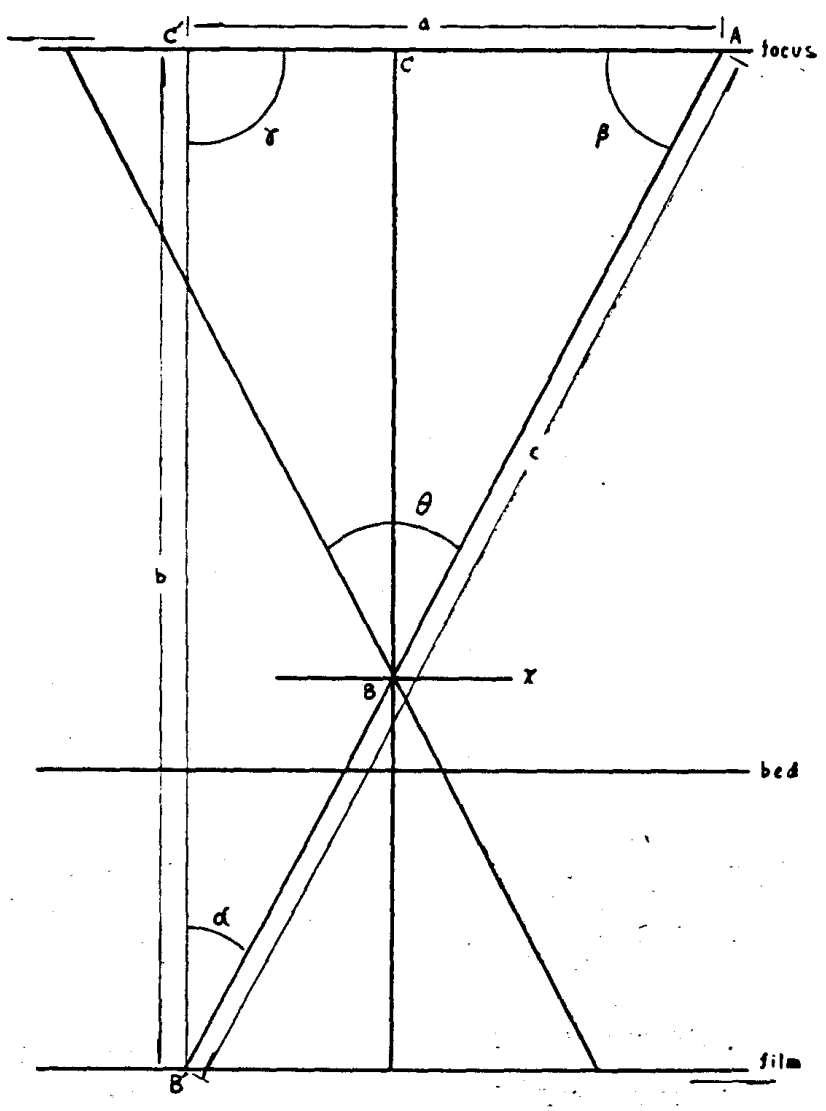

Fig. 3

sifying screen〜film などそれぞれの係数の変化などに よって各角度の tomoにおけるEを一定にするてとは実 に複雑多皮であって，その困難なととは謂う迄すない。

本論では複雑なてとは省略して結果的な見地から極簡 単な計算から進めた。

以下 $E$ 量决定迄の経過を記す。

即ち，(1)式より得られた sec と(2)式により得られた実 角度 $\theta$ 亿よって Fig. 3 の如き， $\triangle A B C \operatorname{Cos} A B^{\prime} C^{\prime}$ の相 似三角形を利して，各角度における fokus film 間の長 さ $c\left(A-B^{\prime}\right)$ と， $a\left(A-C^{\prime}\right)$ を求めると

$$
b\left(C^{\prime} \sim B^{\prime}\right)=1010 \mathrm{~mm} \cdots \text { cost }
$$

とすると

$$
\alpha=\gamma-\beta=\theta \cdot \frac{1}{2}
$$

であるから

$$
a=\tan \alpha \cdot b
$$

であり

$$
c=\sqrt{a^{2}+b^{2}}
$$

となる. Table. 1

次䎲各 $\theta$ 亿おける実効X線量減弱率 $\mu$ は $C$ が垂直の上 き, 即ち $\theta=0^{\circ}$ ときにbとなるから 的長さは $1010 \mathrm{~mm}$ ～const であるのでこの場合の $\mu$ を 


$$
\mu=\frac{b}{b}=\frac{1010}{1010}=1
$$

とするなら

他の $\theta(\alpha)$ の時の $A \sim B^{\prime}$ の長さ, 即ちCの長さは

$$
\mu=\frac{c}{b}=\frac{c}{1010}
$$

となるので $\alpha$ 間のCのみを算出するとよい．

以上の各計算值より略(4)式の $E$ 量は決定できうるもの であるが，てれは管球固定式の略式であって飽迄管球移 動方式の tomoの場合に当嵌るちのでないととは明らか である。

先ず，数式の計算に先立って考えられることは，数の 根源であろう。即ち吾人が被写物体を目前隹して switch を閉しろ前に $\mathrm{mA} \sim \mathrm{kVp} \sim \mathrm{sec} \sim \mathrm{FPD}$ などの適正条件な 万数字が直感的に頭に孚かぶてと汢全て根拠のないもの はなく，理論的な問題と経験的な要素が渾然一体となっ て割出されてくるものであって経験か理論の婁書となる てとすうなずける。いささか自己弁護のようになってて まったが。

故江次化述べんとする数值の現在経験的に最良の条件 で結果が得られたもの、X線写真の基礎こして他の角度 の最適条件を算出してみた。

現在行なっておる標準成人男子 (胸厚 $18 \mathrm{~cm}$ ) の $60^{\circ}$ に おける最適条件は，管電圧 $56 \mathrm{kVP}$ 一管電流 $60 \mathrm{~mA}$ であ る.

曝射時間は(1)式仙って $1.24 \mathrm{~s} s \mathrm{c}$ であると分った。普 通, 露出表の作製には簡略を根本として, 管電圧, 管電 流あるい甠暴射時間または距離などのうち 1 2 を除い て後の一定とする表が多い，てれらの数字は全て変化の できるものを一定こしたものであって㬰際的には余裕が あって容易であるが， tomoのような，特に曝射時間も 角度によって支配される如き装置では，限られたもの一 即ち，管電圧または管電流以外化調節範囲はなく非常に 制約させたものになっている。

従つて露出表の作製には管電圧一管電流の二者によっ て決定させなければならない，また更行簡絜な露出表声 得るに屾両者何れかを一定上するならば筆者の撮影法之 して管電流を $60 \mathrm{~mA}$ 一定とし管電圧のみの調整となし た.

即方, $56 \mathrm{kVp} \sim 60 \mathrm{~mA} \sim 60^{\circ}$ で胸厚 $18 \mathrm{~cm}$ の成人男子 の film 最適条件こするならば，略同一なる黒化度を 得るためては, $\tan \theta 5^{\circ}$ 差每に既略 $2 \mathrm{kV}$ ずつ昇圧させ て $20^{\circ}$ では $72 \mathrm{kVp}$ となるようにして計算を進めてみた。 (4)式の

$$
E=\frac{\mathrm{mAs} \cdot \mathrm{kVp}}{d^{2}}
$$

を基樥とした。

但し， $d^{2}$ は tomoの場合には当嵌めないので，各 $\alpha$ における $C\left(A-B^{\prime}\right)$ を加法して得た積の数值をDとし $\tau$

例 $\cdots \cdots 60^{\circ}$ の場合

$20^{\circ}$ の場合

$$
\begin{aligned}
& \left(32^{\circ} 12^{\prime} \alpha\right) \cdots 2 C= \\
& \left(25^{\circ} 3^{\prime} \alpha\right) \cdots 2 C= \\
& \left(18^{\circ} 38^{\prime} \alpha\right) \cdots 2 C= \\
& \left(13^{\circ} 5^{\prime} \alpha\right) \cdots 2 C= \\
& \left(8^{\circ} 48^{\prime} \alpha\right) \cdots 2 C= \\
& \left.\left(0^{\circ} \quad\right) \cdots 1 C=\right) \\
& \text { D }
\end{aligned}
$$

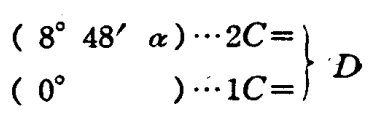

とすると，

(4)式つ $d^{2}$ に $D$ を代入して,

$$
E=\frac{\mathrm{mAs} \cdot \mathrm{kVp}}{D}
$$

とするなら，

Eの值略, 各角度とも近似して值が得られる訳であ 3, (Table. 1)

本来ならば，微積分法を以ってするならば最も精確に

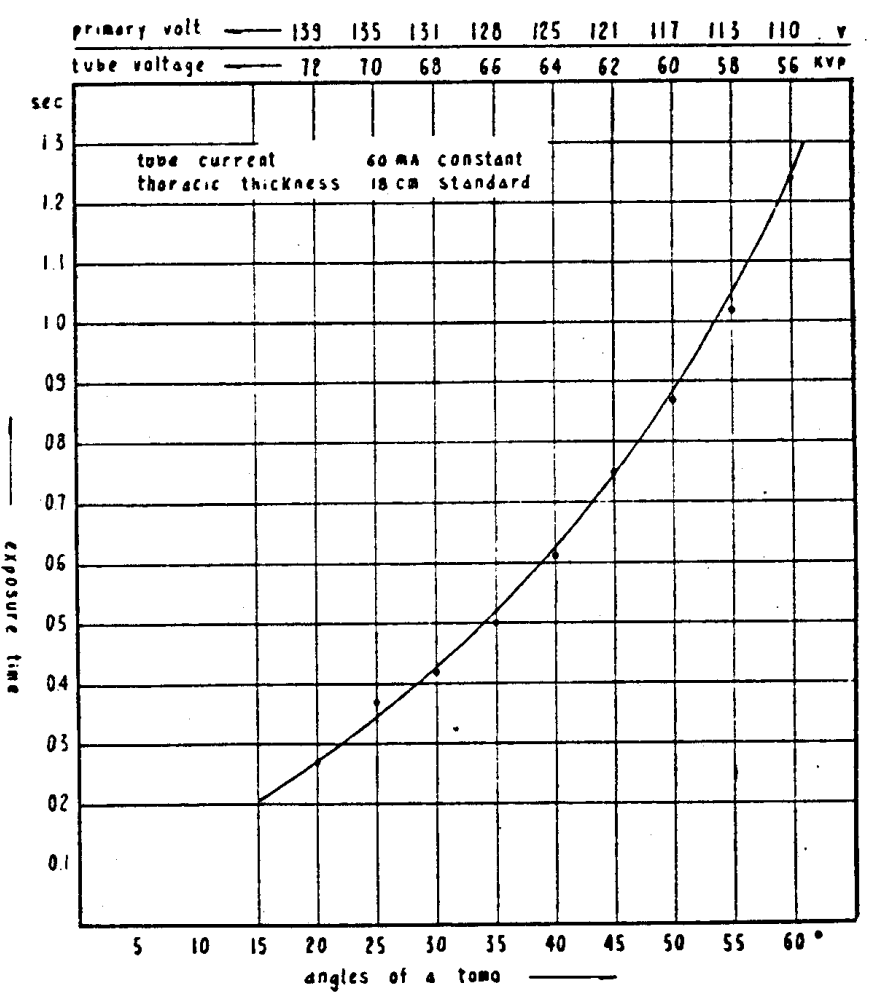

Fig. 4 
でき得るのであるが，実際的には以上の 計算で何等差支えないとみてよからう。

以上の結果を証明するために，先ず Fig. 4 の如き graphを作り, てれ䎲 $\theta=$ $60^{\circ}$ のと $56 \mathrm{kVp} \theta=20^{\circ}$ の時 $72 \mathrm{kVp}$ と なし，ての間に $2 \mathrm{kV} の$ 等間隔をもって 電圧を上昇させて書入れる.

実際的に Fig. 4 の如、縦軸に exposure time を横軸に angles of tomo 等 間隔に目盛って，てれて判明した secを 書込み，てれによって得られた線は直線 でなく曲線となった。

てのgraphに管電圧を書込むのである が曲線に管電圧を等間隔に目盛ることは 当を得たことではないが，簡潔を主とし た点に御留意䫝いたい.

また，管電流は $60 \mathrm{~mA}$ 一定とするか ら，管電圧を $2 \mathrm{kV}$ の等間滆をるってす
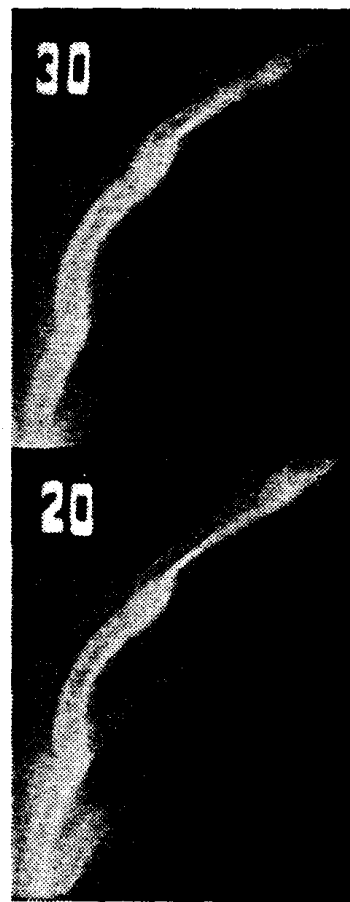

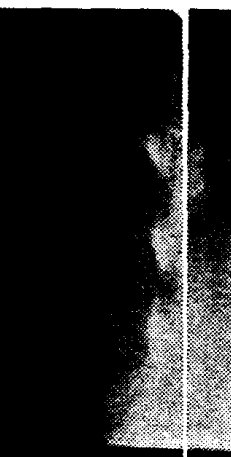

80

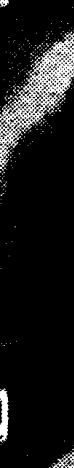

8
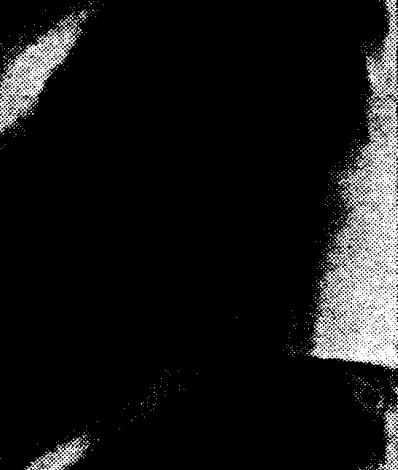

ると，一次電圧計では $3 \sim 4 \mathrm{~V}$ 程度の差であるから実用 上には微細電圧調整器がいに（当科装置では 1 tap 5

V) 精密な調整はできない.しかし撮影に際して同一フ イルムに例えば60度で撮って55度で撮るようなことは殆 どないとみてすよく, 普通の60度と20 35度, あるいは 50度と20〜35度と調う如人角度に差のあるものであって， そう神経賈な問題ではない，即ち $2-3 \mathrm{~V}$ の差は余り影

響はないとみてしかるべきである。

また，本来ならばての detail を更に基礎として Benoist 硬度計をるって硬度の検討をする必要があるが， tomogram の場合には得られた像（銀盤一アルミ階段） にズレが生じて精確な測定は困難である。

従って直接人体を対照として行なったるのが Photo. 3である。

元来, tonography の場合の所渭断面幅によって異な

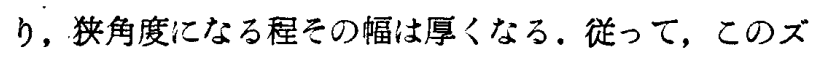
レの凩の変化の黒化度にも影響することは必然的なもの であるし，ての判定は困難であるが，何机にしろ目測に よる判断しか得られないので結果も既念的なるのである。 但し, この Photo. 3 の場合は同一人体及び部使, フ1 ルムも同一乳剤であり，同時現像である故，現像による 濃度の影響沬無視できる。

\section{4. 結語}

以上，吾人が断㬝撮影に際して基本的に不明な点を極 めて簡单に基礎的な追究を行なったに過きなく、てれで
満足したわけでもない，更に深人蓄察，検討を加えたい と思う。

本質的に謂つて斯椂な実験や測定は装置据付時に行う のか技術者としての常識であり今更殊新たまって発表す ること自体が何か間の抜けた気がしないでもない.

内容を一貫して雑なのも気が引けるが, strobo 法検 查にも若干の疑義がないでうない，また材料及び䝷料な どの点について充分でなく精密な detail を出すてとは現 在の処困難であるが，一般診断上にはさして影響はない ちのと考える。

機会があるなら濃度なども density meter で測定しな お一層の精密さを加えたい考えでいる。

以上, 諸兄の御批判, 御此責の的々なるものならば小 論の栄これ以上のものはないと信ずる。

\section{参考 資 料}

1）綱川高美，断首像改善の一考察，日放技誌， $11 \cdot 3$ $14 \sim 16 \mathrm{P}, 1955$

2）、富堅健. 土耳古鞍の断層撮影阅する実験報告.日 放技誌。 $11 \cdot 4.20-21 \mathrm{P} .1956$

3）中泉正徳。臨牧放射線学. 79 -88 P . 1949

4）江藤秀雄. 放射線医学（基礎篇）46 47 P . 1951 